\title{
PENGARUH FITOSTEROL DALAM PAKAN TERHADAP PERTUMBUHAN YUWANA UDANG PUTIH (Penaeus indicus)
}

\author{
Muhammad Marzuqi", Ketut Sugama"), Ketut Suwirya") dan \\ Zafril Imran Azwar
}

\begin{abstract}
ABSTRAK
Percobaan ini bertujuan untuk mengevaluasi kebutuhan fitosterol sebagai substitusi kolesterol dalam pakan terhadap pertumbuhan yuwana udang putih, Penaeus indicus. Percobaan dilakukan di laboratorium pakan dengan menggunakan yuwana dari pemijahan induk udang putih asal tambak. Bobot awal yuwana rata-rata $0,20 \pm 0,023$ g/ekor, ditebar dengan kepadatan 20 ekor/bak. Yuwana udang putih dipelihara dalam 12 bak silinder transparan bervolume 100 liter dengan garis tengah $60 \mathrm{~cm}$ yang diisi air laut 80 liter selama 40 hari. Percobaan menggunakan rancangan acak lengkap dengan empat perlakuan dan tiga ulangan. Perlakuan berupa kadar fitosterol yaitu $0.00 \% ; 1,00 \% ; 2.00 \%$ dan $0,50 \%$ kolesterol digunakan sebagai pakan kontrol. Pakan diberikan dua kali sehari (pagi dan sore) sebanyak 10-15\% dari total biomassa. Hasil percobaan menunjukkan bahwa pertambahan bobot, dan bobot akhir yuwana udang putih yang diberi pakan yang mengandung fitosterol $1,00 \%$ memberikan hasil yang tidak berbeda (masing-masing 569.00\% dan 558,20\%) (P>0,05). Pakan dengan kadar fitosterol 2,00\% bahkan hanya memberikan pertambahan bobot $238,30 \%$ sedangkan pakan yang mengandung $0,50 \%$ kolesterol sebagai pakan kontrol memberikan pertambahan bobot $857,20 \%$. Dalam hal sintasan yuwana, semua perlakuan fitosterol maupun kontrol (kolesterol) tidak memberikan hasil yang berbeda $(P>0,05)$. Hasil percobaan ini menggambarkan bahwa sterol dalam pakan penting untuk pertumbuhan yuwana udang putih dan penggunaan fitosterol belum dapat menggantikan kolesterol untuk mendukung pertumbuhan dan sintasan yuwana udang putih, $P$. indicus.
\end{abstract}

\begin{abstract}
Effect of dietary phytosterol on the growth of Penaeus indicus juveniles. By: Muhammad Marzuqi, Ketut Sugama, Ketut Suwirya and Zafril Imran Azwar.

The purpose of the experiment was to evaluate the dietary phytosterol requirement in substituting cholesterol on the growth of Penaeus indicus juveniles. The experiment was conducted under laboratory condition and Penaeus indicus juveniles derived from pond reared broodstock were tested. Juveniles with initial weight of $0.20 \pm 0.023 \mathrm{~g} / \mathrm{pcs}$ were kept in each 100 liter of transparant silindric tank with $60 \mathrm{~cm}$ of diameter. Each tank was filled with 80 liters of seawater and stocked with 20 juveniles/tank. A completely randomized design was applied with four treatments and three replications. The treatment were different level of phytosterol namely : 0.00\%; $1.00 \% ; 2.00 \%$ and $0.50 \%$ cholesterol as control. The shrimp were fed twice a day (morning and afternoon) at 10-15\% total body weight/day. The result showed that the shrimp fed with diet rontaining $1.00 \%$ phytosterol gave weight gain of $569.00 \%$ in significantly different with those fed with diet rontaining $0.00 \%(558.2 \%$. On the other hand, $2.00 \%$ phytosterol gave only $238.30 \%$ weight gain, while diet with $0.50 \%$ cholesterol as a control, gave the higest weight gain (857.20\%). The finding suggests that phytosterol can not replace cholesterol to support the growth and survival rate of Penaeus indicus juveniles.
\end{abstract}

KEYWORIS: phytosterol; feed; Penaeus indicus.

\section{PENDAHULUAN}

Pakan merupakan faktor penting dalam menunjang keberhasilan budidaya udang secara intensif. Sekitar 60-70\% biaya operasional untuk budidaya udang adalah untuk pakan. Untuk itu penggunaan pakan yang mempunyai nutrisi lengkap dan berimbang perlu mendapat per-

\footnotetext{
Peneliti pada Loka Penelitian Perikanan Pantai Gondol - Bali
} 
hatian. Jumlah dan jenis nutrien dalam pakan seperti lemak (asam lemak), kolesterol, protein (asam amino), karbohidrat, dan vitamin memainkan peranan penting dalam menentukan kualitas pakan.

Beberapa hasil penelitian menunjukkan bahwa lemak khususnya sterol dalam pakan sangat penting untuk memacu pertumbuhan normal udang (Kanazawa et al., 1971; Deshimaru \& Kuroki, 1974; Teshima et al., 1983). Selanjutnya diketahui bahwa kolesterol mempunyai nilai nutrisi yang lebih tinggi untuk udang dan kebutuhan optimum kolesterol untuk pakan udang berkisar 0,50-1,00\% ('Teshima et al., 1983; Kanazawa, 1984; Deshimaru et al., 1985). Akhir-akhir ini telah dikembangkan penggunaan fitosterol sebagai sumber sterol untuk mensubstitusi kolesterol yang harganya relatif mahal. Beberapa fitosterol seperti 24-methylcholesta-5, 22-dienol, dan sitosterol dikatakan merupakan sumber sterol yang efektif untuk pertambahan bobot, konversi pakan dan efesiensi protein yuwana udang Penaeus japonicus (Teshima \& Kanazawa, 1986). Namun demikian Kanazawa et al. (1971) melaporkan bahwa penggunaan ergosterol, stigmasterol dan sitosterol belum sepenuhnya dapat menggantikan fungsi kolesterol pada udang $P$. japonicus. Lebih jauh Teshima et al. (1983) menemukan bahwa penggantian sebagian kolesterol dengan sitosterol dalam pakan yuwana $P$. japonicus dan lobster $H$. americanus ternyata dapat menurunkan pertambahan bobot, FCR, dan PER. Demikian juga D'Abramo et al. (1984) telah membuktikan bahwa fitosterol dan sitosterol dalam pakan tidak dapat menggantikan kebutuhan sterol lobster Humarus sp. Lebih lanjut Teshima et al. (1983) dalam penelitiannya memperoleh bahwa walaupun ergosterol, 24-methylencholesterol, 24-methylcholesta-5, 22-dienol, isofuscosterol, dan chole-7-enol telah digunakan secara efektif untuk mendukung pertumbuhan $P$. japonicus, namun stigmasterol, $\beta$-sitosterol yang keduanya termasuk fitosterol ini, memberikan pertumbuhan yang lebih rendah. Walaupun telah diketahui bahwa fitosterol tidak dapat mensubstitusi kolesterol untuk udang $P$. japonicus, dan lobster, namun informasi tentang pengaruh fitosterol untuk udang putih $P$. indicus belum diketahui. Untuk itu perlu dilakukan percobaan mengenai pengaruh fitosterol sebagai substitusi kolesterol dalam pakan terhadap pertumbuhan yuwana udang putih ( $P$. indicus).

\section{BAHAN DAN METODE}

Percobaan dilakukan di laboratorium pakan Loka Penelitian Perikanan Pantai Gondol. Hewan uji diperoleh dari hasil pemijahan induk udang putih asal tambak. Bobot awal rata-rata hewan uji adalah 0,20 $\pm 0,023$ gram/ekor. Wadah yang digunakan adalah bak silinder transparan bervolume 100 liter dengan garis tengah $60 \mathrm{~cm}$ sebanyak 12 buah yang diisi air laut sebanyak 80 liter. Masing-masing wadah ditebari juwana udang putih sebanyak 20 ekor/bak dan semua bak dilengkapi dengan sistem aerasi.

Percobaan menggunakan rancangan acak lengkap dengan empat perlakuan dan tiga ulangan. Perlakuan yang dicobakan berupa kadar fitosterol dalam pakan dan kolesterol dalam pakan sebagai kontrol (Tabel 1). Bahan perlakuan yang digunakan dalam percobaan ini berupa minyak fitosterol dengan kadar kemurnian sekitar $50 \%$. Bahan ini diproduksi oleh TAMA biochemical Co. Ltd dari Jepang. Minyak fitosterol berisi brassicasterol, campesterol, stigmasterol dan B-sitosterol. Pakan dibuat dalam bentuk pelet dengan karagenan sebagai bahan perekat. Pakan diberikan dua kali sehari (pagi dan sore) dengan dosis 10 $15 \%$ dari total biomassa per hari. Pergantian air. dilakukan setiap hari sebanyak $50 \%$, selama 40 hari percobaan.

Analisis kandungan sterol dalam pakan dan jaringan tubuh udang dilakukan dengan metode ICNND (1963) dalam Azwar (1997). Untuk mengetahui pengaruh perlakuan pakan yang diberikan maka setiap 10 hari dilakukan penimbangan seluruh individu udang. Parameter yang diamati berupa pertambahan bobot, sintasan dan kualitas air. Pada akhir percobaan dilakukan analisis kandungan sterol dalam pakan dan tubuh udang.

\section{HASIL DAN PEMBAHASAN}

Hasil analisis statistik pada akhir percobaan menunjukkan bahwa kadar fitosterol dalam pakan tidak berpengaruh nyata $(\mathrm{P}>0,05)$ terhadap pertambahan bobot, maupun sintasan yuwana udang putih. Di antara perlakuan fitosterol, pertambahan bobot terendah $(238,30 \%)$ justru diperoleh pada penggunaan pakan dengan fitosterol $2,00 \%$. Nilai tersebut jauh lebih rendah bila dibandingkan kadar $0,50 \%$ kolesterol sebagai pakan kontrol yaitu $857,20 \%$ (Tabel 2). 
Tabel 1. Komposisi pakan yang digunakan dalam percobaan.

Table 1. Composition of diets used in the experiment.

\begin{tabular}{|c|c|c|c|c|}
\hline \multirow[t]{2}{*}{$\begin{array}{c}\text { Bahan } \\
\text { Ingredient }\end{array}$} & \multicolumn{4}{|c|}{$\begin{array}{c}\text { Komposisi pakan (\%) } \\
\text { Composition of diets (\%) }\end{array}$} \\
\hline & $\mathbf{A}$ & B & $\mathbf{C}$ & D \\
\hline Kasein (Casein) & 55.00 & 55.00 & 55.00 & 55.00 \\
\hline Pati $(\alpha$-starch $)$ & 8.00 & 8.00 & 8.00 & 8.00 \\
\hline Dekstrin (Dextrin) & 6.00 & 6.00 & 6.00 & 6.00 \\
\hline Sukrosa (Sucrose) & 4.60 & 4.60 & 4.60 & 4.60 \\
\hline Lisin $(L-l y s i n e-H C l)$ & 1.00 & 1.00 & 1.00 & 1.00 \\
\hline Arginin (L-arginine- $\mathrm{HCl}$ ) & 0.20 & 0.20 & 0.20 & 0.20 \\
\hline Metionin (Methionine) & 0.20 & 0.20 & 0.20 & 0.20 \\
\hline Minyak hati ikan cod (Cod liver oil) & 4.00 & 4.00 & 4.00 & 4.00 \\
\hline Campuran vitamin (Vitamin mix) & 5.00 & 5.00 & 5.00 & 5.00 \\
\hline Campuran mineral (Mineral mix) & 6.00 & 6.00 & 6.00 & 6.00 \\
\hline Fitosterol (Phytosterol) & 0.00 & 1.00 & 2.00 & 0.00 \\
\hline Lesitin (Lecithin) & 2.00 & 1.00 & 0.00 & 1.50 \\
\hline Kolesterol (Cholesterol) & 0.00 & 0.00 & 0.00 & 0.50 \\
\hline Karagenan (Carrageenan) & 8.00 & 8.00 & 8.00 & 8.00 \\
\hline Jumlah (Total) & 100.00 & 100.00 & 100.00 & 100.00 \\
\hline
\end{tabular}

A : Kadar $0,00 \%$ fitosterol dalam pakan (Level of $0.00 \%$ diptary phytosterol)

B : Kadar $1.00 \%$ fitosterol dalam pakan (Level of $1.00 \%$ dietary phytosterol)

C : Kadar 2.00\% fitosterol dala in pakan (Level of 2.00 divtary phytosterol)

D : Kadar $0.50 \%$ kolesterol dalam pakan (Level of $0.50 \%$ dietary cholestero)

Tabel 2. Pertambahan bobot dan sintasan yuwana udang putih (Penaeus indicus) dengan kadar fitosterol berbeda dalam pakan.

Table 2. Body weight gain and survival of Penaeus indicus juveniles fed with different levels of phytosterol.

\begin{tabular}{|c|c|c|c|c|}
\hline \multirow{2}{*}{$\begin{array}{c}\text { Kadar fitosterol (\%) } \\
\text { Level of phytosterol } \\
(\%)\end{array}$} & \multicolumn{2}{|c|}{$\begin{array}{l}\text { Bobot tubuh (g) } \\
\text { Body weight (g) }\end{array}$} & \multirow{2}{*}{$\begin{array}{c}\text { Pertambahan } \\
\text { bobot (\%) } \\
\text { Weight gain } \\
\text { (\%) }\end{array}$} & \multirow{2}{*}{$\begin{array}{c}\text { Sintasan (\%) } \\
\text { Survival rate } \\
(\%)\end{array}$} \\
\hline & Awal (Initial) & Akhir (Final) & & \\
\hline 0.00 & $0.20 \pm 0.023$ & $1.32^{b}$ & $558.20^{b}$ & $68.30^{a}$ \\
\hline 1.00 & $0.20 \pm 0.023$ & $1.34^{b}$ & $569.00^{b}$ & $86.80^{\mathrm{a}}$ \\
\hline 2.00 & $0.20 \pm 0.023$ & $0.68 "$ & $238.30^{a}$ & $80.00^{a}$ \\
\hline $\begin{array}{l}0.50 \text { kolesterol } \\
\text { (cholesterol) }\end{array}$ & $0.20 \pm 0.023$ & $1.91^{\circ}$ & $857.20^{c}$ & $68.30^{\mathrm{a}}$ \\
\hline
\end{tabular}

Tabel 2 menunjukkan bahwa kadar fitosterol $0,00 \%$ dan $1,00 \%$ tidak memperlihatkan perbedaan nyata $(P>0,05)$. Walaupun demikian tampak adanya keterkaitan antara kadar fitosterol dengan kadar lesitin dalam pakan percobaan.
Keadaan ini dapat dilihat dari kadar lesitin 2,00\% (pakan A) dibandingkan pakan $B$ yang mengandung kadar lesitin $1,00 \%$, demikian pula pada kadar lesitin $0,00 \%$. Hasil percobaan ini memberi gambaran bahwa lesitin dapat disubstitusi pada 
kadar $1,00 \%$, namun bila kadar lesitin diganti secara keseluruhan dengan fitosterol (pakan C) pertumbuhan yuwana udang putih justru menurun.

Kadar fitosterol dalam pakan dan tubuh udang putih antar perlakuan ditunjukkan pada Tabel 3.

Dari Tabel 3 di bawah tampak bahwa pakan dengan penambahan kadar fitosterol menghasilkan jumlah sterol yang berbeda apabila dibandingkan perlakuan yang tanpa fitosterol ataupun kolesterol. Kondisi kekurangan sterol pada krustasea menyebabkan tingginya tingkat kematian dengan diiringi proses ganti kulit yang tidak sempurna pada yuwana lobster (Homarus sp.). D'Abramo et al. (1984) dalam penelitiannya menyatakan bahwa pemberian pakan tanpa sterol pada lobster Homarus sp. akan menurunkan kadar lemak tubuh dan serum kolesterol.

Pengamatan terhadap beberapa peubah kualitas air meliputi suhu, salinitas, oksigen, nitrit dan amonia selama percobaan masih menunjukkan kisaran yang layak untuk pemeliharaan yuwana udang putih (Tabel 4).

Tabel 3. Komposisi kadar sterol dalam pakan pelet dan tubuh yuwana udang putih (Penaeus indicus) dengan kadar fitosterol berbeda dalam pakan.

Table 3. Sterol composition in pellet feed and body of Penaeus indicus juveniles fed with different levels of phytosterol.

\section{Perlakuan \\ Treatment}

\section{Kandungan sterol dalam pakan \\ Sterol content in pelleted feed (mg/g)}

Kandungan sterol dalam tubuh

Sterol content in juveniles body (mg/g)
$0.00 \%$ fitosterol (Phytosterol)
0.00
0.00
$1.00 \%$ fitosterol (Phytosterol)
2.44
0.14
$2.00 \%$ fitosterol (Phytosterol)
2.59
0.24
$0.50 \%$ kolesterol (Cholesterol)
2.67
0.43

Tabel 4. Kisaran kualitas air selama pemeliharaan juwana udang putih (Penaeus indicus) dengan kadar fitosterol berbeda dalam pakan.

Table 4. Range of water quality parameters during rearing of Penaeus indicus juveniles fed with different levels of phytosterol.

\begin{tabular}{lccccc}
\hline \multirow{2}{*}{$\begin{array}{c}\text { Peubah } \\
\text { Parameter }\end{array}$} & & \multicolumn{5}{c}{ Pakan (Feed) } \\
\cline { 3 - 6 } & & A & B & C & D \\
\hline Suhu (Temperature) & $\left({ }^{\circ} \mathrm{C}\right)$ & $28.3-28.5$ & $28.3-28.4$ & $28.4-28.6$ & $28.5-28.6$ \\
pH & & $7.77-8.00$ & $7.91-8.00$ & $7.96-8.01$ & $7.98-7.95$ \\
Salinitas (Salinity) & $(\mathrm{ppt})$ & $32-35$ & $32-35$ & $32-35$ & $32-35$ \\
Oksigen (Oxygen) & $(\mathrm{mg} / \mathrm{L})$ & $7.97-8.14$ & $8.02-8.05$ & $8.00-8.16$ & $7.70-7.98$ \\
Nitrit (Nitrite) & $(\mathrm{mg} / \mathrm{L})$ & $0.029-0.119$ & $0.033-0.071$ & $0.038-0.207$ & $0.047-0.243$ \\
Amonia (Ammonia) & $(\mathrm{mg} / \mathrm{L})$ & $0.051-0.091$ & $0.071-0.088$ & $0.064-0.251$ & $0.088-0.495$ \\
\hline
\end{tabular}

A : Kadar $0.00 \%$ fitosterol dalam pakan (Level of $0.00 \%$ dietary phytosterol)

B : Kadar $1,00 \%$ fitosterol dalam pakan (Level of $1.00 \%$ dietary phytosterol)

C : Kadar $2.00 \%$ fitosterol dalam pakan (Level of $2.00 \%$ dietary phytosterol)

D : Kadar $0.50 \%$ kolesterol dalam pakan (Level of $0.50 \%$ dietary phytosterol) 


\section{KESIMPULAN DAN SARAN}

- Penambahan kadar fitosterol dalam pakan tidak dapat menggantikan fungsi kolesterol dalam meningkatkan pertumbuhan dan yuwana udang putih ( $P$. indicus), walaupun tidak mempengaruhi sintasannya.

- Pemberian fitosterol dengan kadar 2,00\% justru memberikan pertambahan bobot tubuh terendah dibandingkan perlakuan lain.

\section{DAFTAR PUSTAKA}

Azwar, Z.I. 1997. Pengaruh askorbilfosfat magnesium sebagai sumber vitamin $C$ terhadap perkembangan ovarium dan penampilan larva ikan nila (Oreo(chromis sp.). Disertasi Pasca Sarjana IPB, 180 hal.

D'Abramo. L.R.. C.E. Bordner, D.E. Conclin and N.A. Baum. 1984. Sterol requirement of juvenile lobsters, Homarus sp. Aquaculture, 42: 13-25.

Deshimaru, O, and K. Kuroki. 1974. Studies on purified diet for prawn: II Optimum contents of cholesterol and glucosamine in diet. Bull. Jap. Soc. Sic. Fish., 40: 421-424.

Deshimaru O.. K. Kuroki and Kitamura. 1985. Nutritional quality of compounded diet for prawn Penaeus japonicus. Bull. Jap. Soc. Sci. Fish., 51: 1037-1044.

Kanazawa, A.. N. Tanaka, S. Teshima, and K. Kashiwada. 1971. Nutritional requirement for prawn III. Utilization of the sterol. Bull. Jap. Soc. Sci. Fish., 37: 1015-1019.

Kanazawa, A. 1984. Nutritional of penaeid prawns and shrimps. Proc. First Int. Conf. on the culture of penaeid prawns/shrimps. Iloilo, Philippines, 123 130.

Teshima, S., A. Kanazawa and H. Sasada. 1983. Nutritional value of dietary cholesterol and other sterol to larval prawn Penaetus japonicus. Aquaculture, 31: 159-167.

Teshima, S., and A. Kanazawa. 1986. Nutritive value of sterol for the juvenile prawn. Bull. Jap. Soc. Sci. Fish. 52: 1417-1422.

Teshima, S., A. Kanazawa, S. Koshio and N. Kondo. 1989. Nutritive value of sitosterol for the prawn Penaeus japonicus. Bull. Jap. Soc. Sci. Fish., 55: 153-157. 